\title{
PERAN PEMBINA REMAJA BAGI \\ PERKEMBANGAN PERILAKU REMAJA DI GEREJA KEMAH INJIL INDONESIA TANJUNG SELOR KALIMANTAN UTARA
}

\author{
Jonathan Matheus ${ }^{1)}$, Elisabet Selfina ${ }^{2) *}$ \\ ${ }^{1)}$ Mahasiswa Pascasarjana Prodi Teologi Sekolah Tinggi Theologia Jaffray \\ ${ }^{2)}$ Dosen Pascasarjana Prodi Teologi Sekolah Tinggi Theologia Jaffray \\ ${ }^{*}$ Penulis korespondensi: elisabet.selfina@sttjaffray.ac.id
}

\begin{abstract}
Abstrak
Tujuan dalam penulisan karya ilmiah ini adalah untuk menemukan sejauh mana peranan seorang pembina remaja bagi perkembangan perilaku remaja. Penulisan karya ilmiah ini menggunakan metode kualitatif dan teknik pengumpulan data yang digunakan ialah mengadakan kajian pustaka dengan mengumpulkan data melalui buku-buku dan internet, mengadakan observasi langsung di lapangan dan wawancara kepada objek kajian yaitu para pembina remaja beserta orangtua dan gembala serta pekerja setempat. Adapun kesimpulan karya ilmiah ini adalah peranan seorang pembina remaja dalam perkembangan perilaku remaja yaitu sebagai konselor, sebagai pemimpin yang memiliki visi, sebagai pemimpin rohani, sebagai sahabat, dan sebagai pendoa syafaat. Dengan demikian pembina remaja dapat menghasilkan: Pertama, remaja yang memiliki kualitas pengetahuan firman Tuhan yang baik dan benar sehingga remaja dapat menjalani kehidupan masa remajanya tanpa adanya perubahan perilaku yang menuju pada arah yang negatif. Kedua, dapat dijadikan sebagai acuan yang baik bagi pembina remaja selanjutnya dan dapat mendorong orang tua melakukan hal yang sama pada remaja saat berada dirumah. Ketiga, dapat menumbuhkan rasa percaya diri anak remaja saat mengalami perilaku yang berbeda dan mereka tahu pada siapa dapat mencurahkan masalah yang sedang dihadapinya.
\end{abstract}

Kata-kata kunci: peran, pembina pemaja, perilaku pemaja

The aim of this article is to explore the extent to which the role of a teen mentor impacts the development of youth behavior. This work uses qualitative methods. The author uses a data collection technique, conducting a literature review through gatheringdata from books and the internet, direct field observations, and interviews with research subjects that are all teen mentors, including parents, pastors and local workers. The conclusion of this article is that the role of a youth mentor in the flourishing of adolescent behavior is as a counselor, visionary leader, spiritual leader, friend, and intercessor. Thus a teen mentor can yield several outcomes: First, teens who possess a good and correct knowledge of the God's Word, so that they are able to live their teen years 
without a change in behavior that inclines toward the negative. Second, a good example for future youth mentors and encouragement for parents to do the same while the teens are in the home. Third, foster a teen's self-confidence when they experience different behaviors, as the teen knows they have someone with whom they can share the problems which they are facing.

Keywords: role, teen mentor, teen behavior

\section{Pendahuluan}

Kebutuhan yang paling utama dalam kehidupan remaja dalam proses perkembangan perilaku mereka adalah hadirnya seorang pembina remaja yang sanggup dan memiliki hati yang berkonsentrasi penuh pada remaja terutama saat remaja mulai menceritakan masalah mereka. Namun, keseriusan seorang pembina atau responss pembina saat remaja berbagi kisahnya tidak mendapat umpan balik yang baik dari seorang pembina bagi remaja. Bill Sanders mengatakan:

Pada saat kita sungguh-sungguh mendengarkan, maka mata kita dipusatkan pada pembicara, dan bukan melihat ke sana ke mari atau sekeliling ruangan. Jika kita menunjukkan minat yang sungguh-sungguh, disertai dengan perhatian, kasih, dan rasa ingin melindungi, maka remaja anda akan mulai berbicara. Dengan memberi dorongan kepada mereka, kita dapat membuat mereka mejadi lebih terbuka dan bersedia menceritakan mengapa mereka sedih, mengapa mereka merasa bosan hidup, mereka bersedia menceritakan masalah minuman keras serta obatobatan terlarang, tentang betapa sulitnya menghindari hubungan seks dengan teman lelaki atau perempuan mereka. ${ }^{1}$

Artinya bahwa dampak nyata yang membuat remaja mau berubah dari perilaku mereka adalah ketika seorang pembina bisa menjadi bagian yang dapat menunjukkan cara mereka bereaksi dengan keadaan. Pencarian jati diri, pengakuan, status yang jelas, penghargaan, kepercayaan serta keinginan untuk didengarkan merupakan hal yang dibutuhkan remaja saat ini. David Rice mengatakan:

Cara lain untuk menunjukkan penghargaan kepada remaja adalah menerima keinginan untuk menjadi pribadi yang terpisah. Kita dapat memberikan ini dengan membiarkan mereka untuk berkata tidak. Kadangkadang kita dapat mengkomunikasikan penghargaan tanpa ikut campur urusan orang itu. Dengan tidak berbuat apa-apa dalam satu situasi kita dapat mengkomunikasikan kepercayaan kita. ${ }^{2}$

\footnotetext{
${ }^{1}$ Bill Sanders, Dari Remaja untuk Orang Tua (Bandung: Kalam Hidup, 1995), 55.

${ }^{2}$ David Rice, Mengendalikan Tingkah Laku Anak (Bandung: Kalam Hidup, 1987), 165.
} 
Kecenderungan yang sering dialami remaja dewasa ini adalah ketika mereka melakukan kesalahan maka mereka akan mengalami tindak kekerasan baik secara fisik maupun non fisik. Di sinilah tugas penting pembina remaja untuk bertindak dengan tepat tanpa membuat remaja tersebut semakin terhakimi dengan cara memberikan penegasan dalam tindakan.

\section{Pembina Remaja}

\section{Panggilan Sebagai Pembina Remaja}

Masa remaja adalah masa transisi dari dunia kanak-kanak yang telah ditinggalkan, tetapi masa kedewasaan belum dijalani dengan sungguh-sungguh. Itu sebabnya dalam membangun spiritualitas remaja diperlukan orang-orang dewasa yang terpanggil untuk melayani remaja dan sunguh-sungguh memiliki hati dalam pelayanan remaja. Ivone Palar mengatakan:

Pembina remaja selaku bagian dari struktur organisasi dalam gereja berperan untuk menjaga dan memelihara kehidupan remaja dari awal sehingga para remaja mengetahui jalan kebenaran melalui firman Tuhan setiap hari, di dalam kehidupan remaja, supaya di masa yang akan datang para remaja akan menjadi seorang pribadi yang kuat, berdiri kokoh dalam imannya dan takut kepada Tuhan, sehingga hidupnya menjadi berkat atau berarti bagi sesama remaja maupun lingkungan sekitarnya. ${ }^{3}$

Jadi bukanlah hal yang mudah untuk menjadi pembina remaja karena dibutuhkan panggilan yang benar-benar kuat agar dapat membimbing para remaja dan mempersiapkan mereka memasuki masa remajanya dengan takut akan Tuhan.

Pada saat anak memasuki remaja, kehidupan rohani sangat penting ditanamkan dalam diri mereka, karena pada masa itu remaja susah dipahami. Pembina remaja harus tanggap akan masalah yang terjadi tersebut. Warren S. Benson dan Mark H. Senter II mengatakan bahwa:

Perkembangan rohani remaja sebagai sesuatu yang ditandai oleh realisme yang semakin besar, di mana para remaja mengembangkan sifat kasih yang lebih responssif terhadap Allah daripada posisi sebelumnya. Siap sedia menerima keselamatan, memiliki banyak pertanyaan tentang agama. ${ }^{4}$

\footnotetext{
${ }^{3}$ Ivone Bonyadone Palar, Materi Kuliah PK Remaja-Pemuda (Makassar: STT Jaffray 2010), 7 .

${ }^{4}$ Warren S. Benson dan Mark H. Senter II, Pedoman Untuk Pelayanan Kaum Muda (Bandung: Kalam Hidup, 1993), 60.
} 
Rasa ingin tahu yang besar merupakan salah satu sarana yang dapat dimengerti oleh seorang pembina remaja untuk merangkul remaja melalui pendalaman Alkitab baik tentang keselamatan dalam Kristus maupun untuk menjawab setiap pertanyaan remaja terutama yang berhubungan dengan perkembangan perilaku remaja itu sendiri.

\section{Tugas Seorang Pelayan Pembina Remaja}

Menjadi seorang pembina remaja tidak lepas dari tugas-tugasnya dalam pelayanan remaja itu sendiri. Ada beberapa tugas seorang pembina remaja, diantaranya adalah:

\section{Membangun Pelayanan yang berpusat pada Allah dan bukan pada diri sendiri}

Kecenderungan yang terjadi selama ini adalah para pelayan sering melakukan pelayanan yang tanpa mereka sadari sebenarnya untuk memuliakan dirinya dan bukan Allah. Menurut Watchman Nee, hubungan antar anggota tubuh terlebih dahulu harus melalui kepala, Allah tidak menghendaki di dalam gereja ada kelompok-kelompok, artinya di antara orang Kristen ada sekelompok orang yang memiliki hubungan langsung yang tidak melalui Kepala, yaitu Kristus. ${ }^{5}$

Pendapat ini berarti bahwa seorang pembina remaja haruslah mampu membimbing remaja agar tidak membuat kelompok dalam komunitas gereja melainkan saling berbaur dan tetap berpusat kepada Allah sebagai Kepala gereja, memuliakan Allah dan tidak mencari pujian bagi dirinya sendiri.

\section{Memahami Tugas-Tugas Perkembangan Remaja}

Tugas-tugas perkembangan merupakan ukuran atau pertanda sebagai perkembangan yang normal dari remaja dalam mengarungi hidupnya. Hurlock E. B. mengatakan ada enam tugas perkembangan utama yang dihadapi remaja yaitu: ${ }^{6}$

Pertama, memperoleh hubungan baru dan lebih matang dengan orang lain, baik dengan remaja laki-laki maupun perempuan, pada kelompok seusia. Kedua, mencapai peran sosial sebagai laki-laki atau perempuan. Remaja mengembangkan definisi mereka sendiri tentang apa yang dimaksud pria atau wanita. Ketiga, menerima keadaan fisiknya sebagaimana adanya. Keempat, mencapai kebebasan emosional dari orangtua dan orang dewasa lainnya. Kelima, memperoleh seperangkat

\footnotetext{
${ }^{5}$ Watchman Nee, 12 Bakul (Surabaya: Yayasan Perpustakaan Injil, 1993), 141.

${ }^{6}$ Hurlock, E. B, Psikologi Perkembangan, Suatu Pendekatan Sepanjang Rentang Kehidupan (Jakarta: Erlangga, 1991), 10.
} 
nilai-nilai dan suatu sistem etika sebagai pemandu perilaku mengembangkan suatu ideologi penuntun perilaku pribadi. Keenam, berkeinginan dan berusaha mencapai perilaku yang dapat dipertanggungjawabkan secara sosial.

\section{Mengatur Jadwal Pelayanan Musik dan Pujian}

Pelayanan remaja memerlukan tata ibadah yang disusun dengan baik terutama dalam musik dan puji-pujian. Warren S. Benson dan Mark II. Senter III, mengatakan bahwa kita harus membantu kaum remaja untuk menyadari bahwa mereka sedang melakukan hal yang bermanfaat dan berarti ketika mereka menyanyi. ${ }^{7}$

Pembina remaja harus dapat menjelaskan pada remaja bahwa pada saat mereka menyanyi bukanlah asal menyanyi tetapi mereka sedang memuliakan Allah dan menyenangkan hati Allah melalui pujian mereka. Melibatkan para remaja sejak dini untuk dapat melayani adalah hal yang penting juga untuk dikembangkan bagi pembina remaja agar kerohaniaan remaja dapat berkembang dengan baik dan dalam pemahaman yang benar. Menurut Robert J. Keeley berpendapat bahwa remaja harus menjadi bagian dalam ibadah jemaat, dan sebaiknya mereka juga memiliki kesempatan untuk mengalami sendiri ibadah yang sesuai dalam setiap perkembangannya. ${ }^{8}$

Pendapat ini dapat disimpulkan bahwa para remaja pun memiliki hak yang sama dengan orang dewasa untuk dapat mengikuti serta mengalami lawatan Allah dalam suatu tatanan ibadah dalam jemaat dewasa dan bukan hanya melalui ibadah remaja saja sehingga para remaja dapat bertumbuh dalam pemahaman atau pola pikir yang lebih berwarna.

\section{Membuat Jadwal Besuk Remaja}

Dalam keadaan apapun, sakit atau tidak, remaja butuh perhatian yang lebih dari pembinanya. Sebagai pembina sebaiknya memiliki hubungan yang erat dengan remajanya apalagi bila mengetahui remajanya mengalami sakit maka haruslah segera membesuk baik secara pribadi atau mengajak remaja lainnya. Demikian pula bila ada remaja yang mulai kurang dalam kehadirannya dalam ibadah remaja, maka pembina harus mengunjungi dan memberi semanga bagi mereka agar lebih giat mengikuti ibadah remaja.

\footnotetext{
${ }^{7}$ Warren S. Benson dan Mark II. Senter III, Pedoman Lengkap untuk Pelayanan Kaum Muda (Bandung : Kalam Hidup, 1999), 270.

${ }^{8}$ Robert J. Keeley, Menjadikan Anak-anak Kita Bertumbuh Dalam Iman (Yogyakarta: Penerbit ANDI, 2013), 117.
} 


\section{Perkembangan Perilaku Remaja}

Agar dapat memahami perkembangan perilaku pada remaja maka pembina remaja perlu mengetahui lebih jauh mengenai hal yang ungkapkan oleh Ivone Bonyadone Palar:

Perkembangan psikologi dengan pendekatan Behavioristik untuk menerangkan tingkah laku dimulai oleh J. B. Watson, pada sekitar tahun 1913. Para ahli yang tergabung pada kelompok Behaviorisme ini tidak lagi memusatkan perhatian hanya pada konsep-konsep mentalistik melainkan ingin menunjukkan data dan fakta objekif melalui hasil-hasil percobaan yang dilakukan di laboratorium mengenai tingkah-laku yang dapat dilihat dan dicatat dari luar dan yang dapat diubah-ubah pada kondisi-kondisi tertentu yang ditentukan. Eksperimen mereka terkenal dengan sebutan Stimulus-Respons. Konsep teori S-R ini ialah bahwa tingkah laku diperoleh dari proses belajar. Agar terjadi proses belajar, perlu rangsangan dari luar, yang mungkin terjadi berulang-ulang, dan dengan penguatan melalui cara yang langsung atau tidak langsung menimbulkan dorongan untuk memberi respons atau melalui kondisioning. Stimulus (rangsangan) dari luar dapat diatur dan responsnya (jawaban) dapat dipelajari. ${ }^{9}$

Dapat disimpulkan juga bahwa proses pertumbuhan remaja merupakan proses perkembangan perilaku mereka. Bila seorang pembina remaja ingin melayani pelayanan remaja maka butuh waktu yang lebih agar dapat mengamati dan memantau proses tumbuh kembang remaja dan bagaimana perilaku mereka dalam kesehariannya supaya dapat menolong remaja pada pemahaman dan tindakan yang baik untuk melalui masa tersebut.

\section{Perilaku Positif Remaja}

\section{Berkeinginan Untuk dapat Mandiri}

Ketika remaja mulai merasa bahwa mereka bukan anak-anak lagi, maka mereka akan berusaha untuk mandiri dan tidak tergantung dari orang dewasa. Kadangkala hal ini justru disalah tafsirkan oleh orang tua bahwa mereka tidak membutuhkan mereka lagi. Gary Chapman berpendapat bahwa orangtua atau orang dewasa lainnya justru harus mendorong kemandirian remaja tersebut sambil memenuhi kebutuhan remaja akan kasih. ${ }^{10}$ Dapat disimpulkan juga bahwa di dalam pelayanan

\footnotetext{
${ }^{9}$ Ivone Bonyadone Palar, Materi Kuliah: Teori dan Proses Perkembangan Anak (Makassar: STT Jaffray, 2014), 27-28.

${ }^{10}$ Gary Chapman, The Five Love Languages of Teenagers (Batam: Interaksara, 2003), 199.
} 
remaja diperlukan seorang pembina remaja yang dapat memenuhi kasih yang lebih untuk mengarahkan remaja agar dapat mandiri dengan benar.

\section{Berjiwa Pemimpin}

Remaja dalam pertumbuhannya dapat juga menginginkan dijadikan sebagai idola bagi remaja lainnya sehingga ia memiliki pengikut yang banyak. Apalagi bila remaja sudah mulai mengidolakan pembinanya, maka peran pembina saat melihat keadaan ini haruslah cepat tanggap dan mulai mengarahkan kepada hal yang lebih bermanfaat seperti melibatkan mereka dalam perkunjungan. Jerry Rumahlatu berpendapat bahwa tipe kepemimpinan karismatis memiliki kekuatan energi, daya tarik dan pembawaan yang luar biasa untuk mempengaruhi orang lain, sehingga ia mempunyai pengikut yang sangat besar jumlahnya dan pengawal-pengawal yang bisa dipercaya. ${ }^{\mathrm{ll}}$

Hal tersebut dapat berarti bahwa bila remaja yang berjiwa pemimpin ini dapat diarahkan dengan benar maka ia dan para pengikutnya tersebut dapat dipakai dalam pelayanan yang membutuhkan jumlah anggota yang besar. Misalnya pelayanan perkunjungan, maka pelayanan tersebut akan dapat menghasilkan dampak besar bagi yang dikunjungi.

\section{Perilaku Negatif Remaja}

\section{Mudah Marah}

Kadangkala penyebab seorang remaja mengalami perilaku yang kurang terpuji baik kepada penghargaan pada orang lain maupun pada dirinya sendiri dikarenakan oleh konsep diri yang salah. Singgih D. Gunarsa dan Y. Singgih D. Gunarsa berpendapat:

Baik konsep diri maupun kepribadian merupakan sesuatu yang statis sifatnya, tetapi justru dapat berubah. Hal ini disebabkan karena baik kepribadian maupun konsep diri terbentuk berdasarkan penggabungan tingkah laku-tingkah laku yang mencerminkan keadaan emosi tertentu, pemikiran tertentu, ide tertentu maupun bawaan-bawaan tertentu dan setiap dari tingkah laku ini dapat berubah sehingga kepribadian dan konsep diri pun dapat berubah. ${ }^{12}$

Ini dapat berarti bahwa seorang pembina remaja untuk menangani perilaku remaja yang mudah marah haruslah lebih sabar. Kadangkala bagi anak remaja yang masih labil dapat dengan mudah terbawa sesuai

\footnotetext{
${ }^{11}$ Jerry Rumahlatu, Psikologi Kepemimpinan (Penerbit: Cipta Varia Sarana, 2011), 96.

${ }^{12}$ John M. Drescher, Tujuh Kebutuhan Anak (Jakarta: BPK Gunung Mulia, 2009), 237.
} 
dengan suasana perasaan hatinya. Disinilah fungsi pembina remaja untuk menuntun remajanya agar dapat menangani amarahnya dengan cerdas.

\section{Suka Memberontak}

Dalam masa pertumbuhan yang mencari jati diri, remaja cenderung menginginkan agar supaya apa yang diinginkan dapat tercapai atau terpenuhi. Dampak yang kurang baik bila keinginannya tidak terpenuhi atau tidak sependapat dengan apa yang kita ingin mereka lakukan maka dia akan memberontak. Pembina remaja perlu menangani dengan segera bila ini terjadi pada remaja seperti yang dikatakan Les Morgan bahwa secara sederhana, pemberontakan itu semacam ilalang yang harus disingkirkan. Pemberontakan dapat menyusup diam-diam dan akhirnya menyebabkan kita melawan standar-standar Allah untuk kehidupan kita. ${ }^{13}$

Peran pembina dalam hal ini haruslah membuat remaja dapat mengerti bahwa tindakan memberontak merupakan tindakan yang tidak berkenan di mata Allah. Dan tidak sampai di situ saja sebab pembina harus meluangkan waktu bersama dengan remaja untuk dapat mengendalikan pembawaannya dengan lebih teratasi dan lebih tenang sehingga perilaku yang kurang baik ini dapat remaja lalui dengan lebih terkendali dan tidak merusak.

\section{Peranan Pembina Remaja}

Keberhasilan dalam suatu pelayanan tidak terlepas dari peranan pemimpin yang menangani pelayanan tersebut. Demikian halnya juga dalam pelayanan remaja, peranan seorang pembina sangat dibutuhkan khususnya menghadapi remaja dalam masa perkembangannya. Dalam pelayanan penulis melihat ada beberapa hal yang amat sangat diperlukan oleh para remaja, dan itu menjadi kebutuhan yang harus terpenuhi dalam pelayanan remaja, diantaranya:

\section{Sebagai Konselor}

Konseling merupakan suatu proses yang direncanakan untuk menolong klien yang pada umumnya mengalami masalah secara psikis. Menurut Hadi P. Sahardjo, konseling adalah suatu bentuk pertolongan psikologis yang diberikan oleh seorang konselor Kristen (yaitu seorang yang khusus diperlengkapi untuk tugas itu) terhadap konseli atau klien yang sedang menghadapi masalah untuk dipecahkan bersama. ${ }^{14}$

\footnotetext{
${ }^{13}$ Les Morgan, Mencabut 7 Ilalang Perusak Masa Remaja (Bandung: Kalam Hidup, 2004), 22.

${ }^{14}$ Hadi P. Sahardjo, Konseling Krisis dan Terapi Singkat (Bandung: Pionir Jaya, 2008), 3.
} 
Konseling merupakan wadah yang dapat digunakan dalam membina hubungan antara pembina dan remaja itu sendiri untuk mencapai rasa saling peduli. Dengan konseling maka pembina remaja akan mampu menemukan apakah ada terjadi perkembangan perilaku pada remaja ketika berada dalam komunitas di gereja. Sebagai seorang konselor maka pembina remaja harus memiliki kepekaan untuk melihat bagaimana seorang remaja bereaksi dengan temannya. Yang menjadi poin utama sebagai seorang konselor adalah dapat dipercaya, terutama sebagai konselor pelayanan remaja. Pada masa ini remaja bukanlah sosok yang mudah percaya pada orang lain tetapi bila seorang pembina dapat memberikan rasa percaya kepada remaja yang dilayaninya maka akan tercipta keadaan yang baik yaitu kepercayaan antara konseli dan konselor.

\section{Sebagai Pemimpin yang Memiliki Visi}

Pembina remaja adalah pemimpin dalam pelayanan remaja dan seorang pemimpin perlu memiliki visi yang dapat dimengerti oleh setiap remaja yang dilayaninya. Daniel Ronda mengatakan visi itu penting dan memiliki kekuatan karena semua kepemimpinan yang efektif dapat dilihat dari visinya. ${ }^{15}$

Bagi pembina remaja, memiliki visi yang jelas akan menjadikannya sebagai sosok pemimpin yang kuat dan bahkan akan dapat mempengaruhi orang lain atau remaja itu sendiri dalam memenuhi panggilannya. Dan bukan hanya sampai di situ saja, seorang pemimpin harus pula mampu membawa orang yang dipimpinnya agar masuk dalam setiap rencana atau program yang telah dibuatnya. Hal ini seperti yang dinyatakan oleh Ann Grinnel bahwa pemimpin adalah orang yang dapat memindahkan orang lain dari suatu tempat menuju tempat baru yang sesuai dengan tujuannya. ${ }^{16}$

Dapat disimpulkan bahwa pemimpin yang baik adalah sosok yang mengerti dengan benar apa yang menjadi visinya dalam pelayanan remaja sehingga dapat mengembangkan pelayanan tersebut dengan maksimal terutama dalam mengamati perkembangan perilaku pada remaja yang sangat membutuhkan sosok pemimpin yang berkualitas.

\section{Sebagai Pembimbing Spiritual}

Dunia remaja identik dengan pembentukan dan pencarian identitas yang di dalamnya juga dapat mempengaruhi perilaku. Oleh karena itu remaja perlu mendapatkan perhatian khusus dari pembinanya. Karena biasanya seorang remaja akan selalu lebih memperhatikan bukti nyata

\footnotetext{
${ }^{15}$ Daniel Ronda, Leadership Wisdom (Bandung: Kalam Hidup, 2011), 15.

${ }^{16}$ Ann Grinnel, Pedoman Kepemimpinan Kaum Muda Dream Big Start Small (Jakarta : Departemen Pemuda GKII dan Departemen Pemuda C\&MA, 2011), 119.
} 
dari apa yang dilihatnya, termasuk kehidupan keseharian dari pembinanya. Pendapat senada seperti yang dikemukakan oleh Anni Dyck yang mengatakan bahwa:

Sebagai remaja ia percaya pada apa yang orang tua atau gurunya percayai termasuk yang pembina remaja ajarkan kepadanya. Tetapi sekarang ia harus menemukan kebenaran firman untuk diri sendiri. Ada remaja yang sudah menyerahkan hidupnya pada Tuhan dalam masa anak, dan karena itu kegoncangan rohani tidak sehebat seperti yang dialami oleh kawankawan yang lain. Meskipun begitu, hubungan dengan Allah harus diperdalam untuk mendapatkan jawaban atas banyak pertanyaan yang timbul sekarang. ${ }^{17}$

Untuk menumbuhkan pemahaman kekristenan yang benar pada remaja maka diperlukan seorang pembina yang juga memiliki tingkat pemahaman kerohanian yang baik. Pemahaman tentang siapakah Yesus sebagai juruselamat agar pembina dapat membimbing remaja yang mungkin mengalami masalah dalam perkembangan perilakunya. Selain dapat memberikan pengajaran yang tepat bagi para anak remaja, seorang pembina remaja juga harus jeli dalam melihat pola perilaku pada remaja dan bagaimana perkembangan perilaku para remaja yang akan dibimbingnya.

Senada dengan pendapat itu Howard G. Hedricks mengatakan bahwa sebagai pengajar yang efektif, bukan hanya harus tahu apa yang akan diajarkan atau isi pengajaran, tetapi juga harus tahu siapa orangorang yang akan diajar. ${ }^{18}$ Pendapat ini berarti bahwa pembina remaja sebagai pengajar atau pembimbing rohani haruslah tahu bagaimana cara menyampaikan pengajaran firman Tuhan dengan baik sesuai usia remaja yang dilayaninya.

\section{Sebagai Sahabat}

Masa remaja dapat pula berarti sebagai masa di mana remaja membutuhkan sahabat. Sahabat yang dapat dipercaya sebagai tempat mereka mengungkapkan perasaannya yang bergejolak sekaligus sahabat yang dapat diandalkan untuk mengerti dan menjaga rahasia mereka. Dalam hal ini pembina remaja dapat hadir sebagai sosok tersebut untuk mengajak remaja terbuka kepadanya. Seperti yang dikemukakan oleh Linda dan Richard Eyre bahwa berbincanglah dengan remaja tentang

\footnotetext{
${ }^{17}$ Anni Dyck, Tantangan Dan Kebutuhan Remaja, Seri Pendidikan Kristen 3 (Malang: Dept. PAP/YPPII, 2001), 55-56.

${ }^{18}$ Howard G. Hendricks, Mengajar Untuk Mengubah hidup (Jakarta: Gloria Graffa, 2009), 45.
} 
mengapa mereka demikian, juga tentang alasan-alasan dan sebab-sebab yang mungkin di balik cara orang memandang suatu masalah. ${ }^{19}$

Pendapat ini bermakna bahwa saat mengalami masalah biasanya remaja akan mencari pelarian dari situasi yang dihadapinya. Hal inilah yang biasa menjadikan perilaku remaja berubah. Kesediaan pembina untuk menjadi sahabat bagi remaja dapat menimbulkan keterbukaan remaja untuk berbagi situasi yang mereka alami sekaligus menerima masukan yang baik dari pembinanya.

\section{Sebagai Pendoa bagi Remaja}

Dalam masa proses tumbuh kembangnya, remaja sangat membutuhkan peneguhan dari orang lain. Bila mereka tidak menemukannya di rumah maka mereka akan mencarinya dari orang di luar rumahnya. Di sinilah peran seorang pembina dibutuhkan yaitu untuk menjadi seorang pendoa bagi remaja yang dididiknya. Untuk dapat mendoakan remajanya, pembina haruslah seorang yang gemar berdoa. Jadi, pembina remaja yang terpanggil dalam pelayanan remaja harus menjadi seorang yang memberi pola pada remajanya bahwa mereka adalah sosok pendoa. Pembina remaja dapat menunjukkan bahwa ia terbeban menjadi pendoa bagi pertumbuhan remaja dalam menghadapi pergolakan perilaku mereka.

Andy Stanley mengatakan:

Kita melihat apa yang sedang kita cari. Kita sering tidak melihat apa yang kita harapkan tidak untuk melihatnya. Doa membuat kita terus melihat. Doa membuat beban kita selalu segar. Doa membuat mata dan hati kita berada pada kondisi berharap. Doa tidak memaksa tangan Allah. Tetapi doa membuat kita tetap menantikan campur tangan-Nya. Doa membuat kita peka dengan perubahan-perubahan yang tak terlihat di permukaan situasi kita. ${ }^{20}$

Seorang pembina remaja yang gemar berdoa akan memberikan dampak yang besar kepada remaja binaannya dalam hal iman. Karena remaja akan belajar bagaimana menyampaikan segala harapan dan keinginannya kepada Allah dan mempercayai kata demi kata yang sudah diucapkan dalam doanya untuk digenapi bagi kehidupan mereka. Memang tidak mudah untuk dapat mencapai hal ini. Diperlukan waktu yang lebih untuk mendoakan remaja dengan teratur dan sungguhsungguh. Apalagi dengan tantangan melalui sarana media komunikasi

\footnotetext{
${ }^{19}$ Linda dan Richard Eyre, Mengajarkan Nilai-Nilai kepada Anak, (Jakarta: Penerbit Gramedia Pustaka Utama, 1999), 130.

${ }^{20}$ Andy Stanley, Visioneering (Yogyakarta: Penerbit ANDI, 1999), 31.
} 
dan jaringan, yang dapat saja menjerumuskan remaja dalam dosa dan menghilangkan gairah untuk berdoa.

Pembina remaja harus menyampaikan kepada remaja bahwa dalam doa, remaja dapat mempunyai harapan yang besar bagi keberhasilan sahabatnya, orang tuanya, bahkan mungkin teman sebayanya yang berbeda keyakinan. Dengan kata lain bahwa remaja dapat memberkati kehidupan sahabatnya siapapun mereka bahkan bagi pembina remaja mereka dalam doanya.

\section{Metodologi Penelitian}

\section{Populasi dan Sampel}

Yang menjadi populasi dan sampel dalam penelitian penulis adalah berfokus hanya kepada anak remaja tengah usia 14-17 tahun yang sangat setia dalam menghadiri ibadah remaja yang berjumlah 17 orang, ${ }^{21}$ pembina remaja, orang tua, gembala, asisten 3 dan tenaga PKL.

\section{Teknik Pengumpulan Data}

Dalam penulisan ini penulis menggunakan beberapa teknik pengumpulan data yang berkaitan dengan pokok yang penulis bahas, yaitu literatur, survei dan wawancara. ${ }^{22}$ Maka metode yang digunakan penulis adalah metode kualitatif dengan teknik pengumpulan data;

Pertama, penulis melakukan kajian pustaka yaitu melalui buku-buku yang berhubungan dengan peranan pembina remaja bagi perkembangan perilaku remaja.

Kedua, menggunakan metode wawancara ke objek kajian, yang pertama wawancara langsung kepada Gembala Sidang GKII Tanjung Selor, asisten gembala dan tenaga PKL dengan tujuan mengetahui seberapa besar peran pembina remaja di lokasi penelitian penulis. Kedua, wawancara kepada anak remaja dengan tujuan untuk mengetahui sejauh mana peran pembinaan remaja bagi perkembangan perilaku remaja di GKII Tanjung Selor Kalimantan Utara.

\section{Teknik Analisis Data dan Pembahasan}

Data yang diperoleh dianalisis oleh penulis untuk diuji kebenarannya melalui suatu wawancara yang telah penulis lakukan kepada responsden dan akhirnya diperoleh data tentang bagaimana peranan pembina remaja bagi perkembangan perilaku remaja di GKII Tanjung Selor di Kalimantan Utara. Kemudian penulis menganalisis data tersebut, lalu mengolah dan menyimpulkannya dalam bentuk uraian.

\footnotetext{
${ }^{21}$ Eli Kuleh, Wawancara oleh Penulis, Tanjung Selor, 18 Mei 2014.

${ }^{22}$ Moh. Natsir, Metode Penelitian (Jakarta: Ghalia Indonesia, 1988), 211.
} 


\section{Analisis Data dan Hasil Penelitian}

\section{Analisis Interpretasi Data}

Pertanyaan-pertanyaan yang penulis ajukan melalui wawancara terbagi dalam dua kategori, yaitu pertanyaan mengenai peran pembina remaja dan hubungan remaja dengan pembinanya dikaitkan dengan perkembangan perilaku remaja.

Pertanyaan yang berhubungan dengan peranan pembina remaja bagi perkembangan perilaku remaja adalah berupa pertanyaan yang menyangkut pentingnya seorang pembina remaja bagi remaja dalam perkembangan perilaku mereka, apakah ada hal-hal khusus yang dilakukan pembina bagi remajanya, kendala apa saja yang dihadapi pembina dalam pembimbing remaja, apakah ada perubahan perilaku remaja selama proses pembinaan, apakah ada dukungan dari orang tua kepada pembina remaja dalam proses perkembangan perilaku remaja, dan pertanyaan-pertanyaan yang berkaitan dengan pelaksanaan fungsi tugas pembina remaja dalam perkembangan perilaku remaja yang dilayaninya.

\section{Peran Pembina Remaja}

\section{Konselor}

Pertanyaan ini berisi bagaimana pembina menjadi bagian yang sangat penting khususnya dalam perkembangan perilaku remaja. Pertanyaan pertama berkisar pada peran pembina remaja sebagai Konselor. Dari hasil wawancara, 4 dari 5 orang pembina remaja mereka mengatakan bahwa mereka belum mengajarkan tentang manfaat dari konseling sehingga remaja belum pernah dikonseling, di samping itu disebabkan karena belum ada remaja yang secara terbuka meminta bantuan konseling pribadi dan kalaupun ada kadang terbentur dengan waktu mereka sebagai pegawai negeri dan aparat negara seperti yang dikemukakan oleh ibu Sinang. ${ }^{23}$

Dan bagi anak remaja, melalui angket dengan pertanyaan terbuka mengenai peran pembina sebagai konselor, 16 dari 17 orang remaja menjawab bahwa mereka belum pernah mendapatkan pelayanan konseling bahkan ada yang tidak mengerti apa itu pelayanan konseling seperti yang disampaikan oleh Harju Sanus. ${ }^{24}$ Sedangkan dengan pertanyaan yang sama kepada orang tua melalui wawancara langsung maka 1 dari 3 orang tua berpendapat bahwa konseling mungkin saja ada

\footnotetext{
${ }^{23}$ Sinang Yesaya, Wawancara oleh Penulis, Tanjung Selor, 17 Mei 2014.

${ }^{24}$ Harju Sanus, Wawancara oleh Penulis, Tanjung Selor, 18 Mei 2014.
} 
dilakukan namun sebatas pengetahuan antara pembina dan remaja yang dikonseling, sesuai pendapat dari Ibu Elam Unya. ${ }^{25}$

Jadi dapat disimpulkan melalui pertanyaan ini bahwa peranan pembina remaja sebagai Konselor belum dipolakan atau diajarkan dalam pelayanan, sehingga pembina remaja belum mengerti fungsi konseling yang dapat membantu mereka menghadapi remaja khususnya perilaku remaja.

\section{Pemimpin Yang Memiliki Visi dan Pembimbing Spiritual}

Pertanyaan kedua dan ketiga berkisar pada peran pembina remaja sebagai seorang pemimpin yang memiliki visi dan sebagai pembimbing spiritual. Dari hasil wawancara 3 dari 5 orang pembina mengatakan bahwa mereka memiliki visi yang telah disampaikan kepada remaja serta telah melaksanakan peran mereka sebagai seorang pembimbing spiritual, yaitu selalu mempersiapkan tata ibadah serta firman Tuhan dengan matang dan bervariasi di tiap minggunya, seperti yang dikatakan oleh Eli Kuleh. $^{26}$

Remaja diberikan angket dengan pertanyaan terbuka mengenai penyerapan firman Tuhan yang disampaikan serta seberapa jauh mereka mengerti visi pembinanya. Maka, 11 dari 17 orang remaja menjawab bahwa mereka percaya pembinanya mempersiapkan dengan baik firman Tuhan yang disampaikan. Hanya mereka mudah lupa dengan apa yang menjadi inti pembahasan karena penyampaiannya kadang monoton atau kurang berkesan. Di samping itu juga ada remaja yang sering main waktu firman Tuhan disampaikan. Tetapi mengenai visi dari pembinanya para remaja sangat mengerti, seperti yang disampaikan oleh salah satu remaja yaitu Rio. ${ }^{27}$

Sedangkan menurut orang tua dengan pertanyaan yang sama pada saat wawancara, 1 dari 3 orang tua berpendapat bahwa ketika mereka menanyakan kepada anak remajanya tentang visi pembina maka remaja dapat menjelaskannya. Tetapi ketika ditanya mengenai hal menarik yang di dapat ketika mengikuti ibadah remaja, maka remaja menjawab mereka senang sebab ada game, asyik dan lucu, bukan karena mereka mengerti makna firman Tuhan yang disampaikan. Dalam arti remaja tidak dapat menceritakan inti yang didapatkannya, seperti yang disampaikan oleh Bapak Dominggus Laway. ${ }^{28}$

Kesimpulan melalui pertanyaan ini adalah bahwa peranan pembina remaja sebagai pembimbing rohani belum berjalan dengan baik walaupun visi dari para pembina dimengerti oleh para remaja. Menurut

\footnotetext{
${ }^{25}$ Elam Unya, Wawancara Oleh Penulis, Tanjung Selor, 16 Mei 2014.

${ }^{26}$ Eli Kuleh, Wawancara Oleh Penulis, Tanjung Selor 18 Mei 2014.

${ }^{27}$ Rio, Wawancara Oleh Penulis, Tanjung Selor 16 Mei 2014.

${ }^{28}$ Dominggus Laway, Wawancara Oleh Penulis, Tanjung Selor, 19 Mei 2014.
} 
penulis hal ini mungkin dapat disebabkan karena pengulangan materi dan penekanan inti firman Tuhan yang disampaikan tidak dilakukan, sehingga apa yang disampaikan kurang dipahami oleh remaja.

\section{Sahabat}

Pertanyaan keempat berkisar pada peran pembina remaja sebagai seorang Sahabat. Dari hasil wawancara, 4 dari 5 orang pembina mengatakan bahwa mereka sudah berusaha menjadi sahabat bagi para remaja binaannya. Caranya dengan cara berbaur bersama mereka di dalam dan di luar ibadah, seperti yang disampaikan oleh Korie Henock. ${ }^{29}$ Bagi anak remaja, melalui angket dengan pertanyaan terbuka mengenai pembina yang menjadi sahabat remaja, 16 dari 17 orang remaja menjawab bahwa mereka bisa menjadikan pembinanya sebagai sahabat. Walaupun ada satu orang remaja yang beranggapan bahwa pembina belum dapat dijadikan sahabat karena alasan perbedaan umur yang jauh, seperti yang disampaikan oleh Nando. ${ }^{30}$ Sedangkan menurut orang tua dengan pertanyaan yang sama melalui wawancara langsung dengan penulis, 2 dari 3 orang tua berpendapat bahwa pembina remaja telah menjadi sahabat yang baik bagi remaja, walaupun mungkin belum semuanya melakukan hal yang sama, seperti yang disampaikan oleh Ibu Loveris. ${ }^{31}$

Jadi dapat disimpulkan melalui pertanyan ini, bahwa peranan pembina remaja sebagai Sahabat hampir memenuhi target. Walaupun masih ada sedikit kendala yang menghalangi yaitu remaja berpikir faktor usia yang berbeda jauh membuat mereka tidak dapat lebih leluasa mencurahkan keadaan mereka. Menurut penulis hal ini mungkin saja terjadi disebabkan pembina masih menempatkan posisinya sebagai seorang yang harus dihormati dan remaja harus tahu batasan dalam bersikap. Padahal yang diinginkan remaja adalah sebaliknya. Remaja ingin agar pembina dapat menjadi pribadi yang asyik untuk dijadikan tempat curhat layaknya sahabat dekat mereka tanpa adanya batasan.

\section{Pendoa bagi remaja}

Pertanyaan kelima berkisar pada peran pembina remaja sebagai seorang Pendoa. Dari hasil wawancara, 4 dari 5 orang pembina mereka mengatakan bahwa mereka selalu mendoakan remajanya. Bahkan mereka secara rutin memasukkannya sebagai pokok doa dalam ibadah raya maupun ibadah lainnya, seperti yang dikatakan oleh ketua pembina remajanya. Tetapi mengenai seberapa sering pembina mendoakan remajanya, penulis tidak mendapatkan jawaban yang pasti. Bagi anak remaja, diberikan angket dengan pertanyaan terbuka mengenai pembina

\footnotetext{
${ }^{29}$ Korie Henock, Wawancara oleh Penulis, Tanjung Selor, 14 Mei 2014.

${ }^{30}$ Nando, Wawancara oleh Penulis, Tanjung Selor, 19 Mei 2014.

${ }^{31}$ Loveris, Wawancara oleh Penulis, Tanjung Selor, 13 Mei 2014.
} 
yang menjadi Pendoa bagi remaja. Hasilnya 10 dari 17 orang remaja menjawab bahwa mereka tidak yakin pembinanya setia mendoakan mereka setiap saat. Walaupun mereka tahu bahwa dalam doa di ibadah minggu ada remaja yang didoakan, namun mereka berpendapat bahwa pembina mungkin berdoa bagi mereka hanya bila diperlukan atau sesuai permintaan dalam pokok doa saja, seperti yang diungkapkan oleh Titin. ${ }^{32}$ Sedangkan menurut orang tua dengan pertanyaan yang sama melalui wawancara langsung dengan penulis, 1 dari 3 orang tua berpendapat bahwa pembina remaja mungkin saja dapat mendoakan remaja mereka dengan jam doa yang tetap, diminta atau tidak. Tetapi dalam setiap minggu sudah terpola secara rutin pokok doa, salah satunya melalui warta jemaat tentang kebutuhan doa remaja dan itupun bila remaja melaporkan kebutuhan doanya, seperti yang telah disampaikan oleh Ibu Lusia Kaleb. ${ }^{33}$

Jadi dapat disimpulkan melalui pertanyan ini, bahwa peranan pembina remaja sebagai Pendoa belum dilakukan fungsinya secara maksimal. Hal ini disebabkan karena doa yang dilakukan hanya dikonsentrasikan pada daftar pokok doa di warta jemaat. Misalnya remaja yang sedang berulang tahun, yang sakit, atau yang akan menghadapi ujian. Penulis berpendapat bahwa pembina remaja dalam hal ini hanya melakukan doa pada remaja hanya bila disampaikan sesuai permintaan dan bukan karena beban atau kerinduan pribadi untuk mendoakan remaja yang dilayaninya.

Tetapi secara jelas dan tegas ketika penulis bertanya kepada setiap orang tua mengenai apakah mereka mendukung pelayanan remaja maka semua menjawab bahwa mereka sangat mendukung pelayanan tersebut. Sebab orang tua melihat adanya perubahan pada diri anak remajanya setelah mengikuti ibadah. Dukungan orang tua dapat berupa saran, nasehat maupun dana bila diperlukan.

Disamping itu penulis juga mengadakan wawancara langsung kepada gembala sidang GKII Tanjung Selor, asisten 3 dan tenaga PKL, untuk mengetahui sejauh mana peran pembina remaja dalam menangani remaja dan perilakunya. Sekaligus juga sebagai penguat hasil angket pertanyaan terbuka kepada remaja dan wawancara langsung dengan pembina dan orang tua. Dari hasil wawancara tersebut penulis mendapati bahwa remaja cukup mengalami perubahan khususnya perilaku mereka yang lebih baik saat aktif mengikuti ibadah remaja. Walaupun memang tidak secara drastis dan langsung para remaja terlihat lebih sopan, lebih tenang, lebih terbuka dan lebih giat dalam setiap kegiatan remaja lainnya. Pernyataan ini penulis dapatkan dari

\footnotetext{
${ }^{32}$ Titin, Wawancara oleh Penulis, Tanjung Selor, 15 Mei 2014.

${ }^{33}$ Lusia Kaleb, Wawancara oleh Penulis, Tanjung Selor, 18 Mei 2014.
} 
hasil wawancara bersama gembala sidang GKII Tanjung Selor. ${ }^{34}$ Jadi penulis dapat menyimpulkan bahwa dengan adanya perhatian yang lebih dari pembina bisa memberi dampak yang baik bagi perkembangan perilaku remaja walaupun tidak secara langsung dan cepat.

Dari hasil wawancara dengan asisten 3 GKII Tanjung Selor, penulis menanyakan apa yang menjadi harapannya bagi remaja yang ditangani oleh pembina remaja khususnya dalam perilaku mereka. Penulis mendapat jawaban bahwa seorang pembina harus memiliki hati yang mengasihi pelayanan remaja yang meluangkan waktu khusus untuk menangani remaja. Apabila ia menemukan ada remaja yang mempunyai perilaku yang negatif, segera dibimbing. Bagi perilaku remaja yang positif dapat dimaksimalkan dalam pelayanan. Pembina remaja juga seharusnya menambah pengetahuan mereka tentang remaja untuk memudahkan dalam menangani remaja, seperti kata asisten 3 saat wawancara dengan penulis. 35

Hasil wawancara tersebut, penulis menarik kesimpulan bahwa pembina remaja tidak boleh cepat puas dengan pelayanan remaja yang telah berjalan. Pembina perlu melatih diri lebih lagi untuk mengenal remaja, dengan cara mengikuti seminar atau pelatihan-pelatihan yang berhubungan dengan pelayanan remaja sehingga pelayanannya menjadi maksimal.

Sedangkan wawancara dengan tenaga PKL, penulis menanyakan bagaimana perilaku remaja selama ini sesuai pengamatannya. Hasil yang penulis dapatkan adalah remaja sekarang tidak menunjukkan perilaku yang terlalu mengkhawatirkan. Sebab biasanya ketika remaja ingin mencari jawaban atas apa yang ingin mereka ketahui, ada beberapa pembina yang siap menangani mereka. Walaupun kadang-kadang ada remaja yang hanya datang pada pembina yang mereka sukai dikarenakan adanya kedekatan secara emosi. ${ }^{36}$

Hasil wawancara tersebut, penulis menarik kesimpulan bahwa untuk menarik perhatian remaja agar dapat menjadikan pembina sebagai sosok yang selalu dekat dengan remaja, dalam segala keadaannya terutama bagi remaja yang selalu membutuhkan perhatian lebih bagi perkembangan perilakunya, maka diperlukan pembina yang memiliki totalitas waktu pelayanan yang penuh dan bukan dikarenakan hanya untuk memenuhi kekosongan struktur dalam pelayanan.

\footnotetext{
${ }^{34}$ Irang Buding, Wawancara oleh Pembina, Tanjung Selor, 19 Mei 2014.

${ }^{35}$ Ismail Tago'a, Wawancara oleh Pembina, Tanjung Selor, 19 Mei 2014.

${ }^{36}$ Resina Lokbere (Tenaga PKL), Wawancara oleh Penulis, Tanjung Selor, 12 Mei
} 2014. 


\section{Kesimpulan Hasil Analisis}

Adapun yang merupakan kebutuhan dari remaja melalui wawancara yaitu:

Pertama, remaja membutuhkan pembina yang dapat mengerti tumbuh kembang mereka terutama yang menyangkut pada perkembangan perilaku. Remaja perlu dikonseling dan itulah kebutuhan yang pertama. Tetapi bagaimana mereka dapat dikonseling sedangkan remaja belum pernah mendengarkan tentang makna atau manfaat dari konseling itu sendiri. Sebenarnya bila pembina sudah menjadikan konseling sebagai bagian dari pelayanannya, maka penulis percaya bahwa pelayanan remaja akan menjadi pelayanan yang besar sebab para remaja dapat mengatasi perilaku mereka dengan baik yang merupakan hasil dari konseling pembinanya.

Kedua, kebutuhan remaja terhadap pembina mereka adalah selalu menyampaikan visinya. Sehingga setiap remaja baik yang setia maupun tidak, baik yang sudah lama mengikuti ibadah remaja maupun yang baru bergabung dapat mengerti visi pembinanya dengan jelas. Jadi penyampaian visi yang berulang disampaikan pada remaja akan membantu mereka mengerti visi pembinanya.

Ketiga, yang menjadi kebutuhan anak remaja bagi pembinanya adalah bimbingan rohani. Remaja membutuhkan bimbingan rohani tidak hanya ketika mengikuti ibadah remaja saja tetapi setiap hari bahkan setiap saat terutama bila berdampak pada perilaku mereka. Remaja membutuhkan sosok yang lain untuk membimbing kerohanian mereka selain orang tua dan gereja. Justru kadang remaja memilih beribadah dalam komunitasnya selain di ibadah raya hanya untuk mendapatkan perhatian lebih dari pembinanya. Seperti yang dikatakan saudari Rima. ${ }^{37}$ Dari wawancara tersebut maka penulis menarik kesimpulan bahwa bimbingan rohani yang baik dan tepat pada remaja mampu menciptakan rasa nyaman dalam komunitas rohani sebayanya.

Keempat, kebutuhan yang anak remaja inginkan pada pembinanya adalah sebagai sahabat. Remaja-remaja merasa bahwa merekapun membutuhkan sosok sahabat yang dapat mengerti dan bisa dipercaya saat mereka mengutarakan perasaannya, rasa sedihnya, kegembiraannya ataupun kemarahannya. Remaja kadang menemukan sahabat sebayanya yang justru membuat mereka kecewa. ${ }^{38}$ Belum ditemukannya pembina yang tepat dan dapat menjadi sahabat yang bisa dipercaya dengan baik, layaknya seorang sahabat dalam pengertian mereka, akhirnya membuat remaja memiliki perilaku yang negatif sebagai tuangan ekspresi mereka.

Kelima, hal lain yang juga merupakan kebutuhan anak remaja yaitu didoakan. Selain iman yang besar kepada Tuhan untuk mengendalikan

\footnotetext{
${ }^{37}$ Rima Putri, Wawancara oleh Penulis, Tanjung Selor, 19 Mei 2014.

${ }^{38}$ Hana Mitha, Wawancara oleh Penulis, Tanjung Selor, 19 Mei 2014.
} 
hidup mereka, sebagian remaja yakin bahwa kuasa doa memegang peranan yang penting dalam mereka menjalani aktivitas kesehariannya. Ini merupakan hal yang baik dari salah satu perilaku remaja karena tidak semua mau melakukan doanya dengan rutin, tertib dan teratur. Remaja membutuhkan pihak lain untuk mendukung semangat mereka, impian mereka, harapan dan cita-cita mereka terlebih masa depan mereka. Di sinilah peranan pembina sebagai pendoa syafaat bagi remaja yang dilayaninya. Merasa lemah dan membutuhkan dukungan doa selalu merupakan kerinduan remaja. Tetapi menurut penilaian beberapa remaja, mereka yakin pembinanya mendoakan mereka, hanya seberapa sering pembina melakukannya tidak diketahui oleh remaja. Tetapi bila melihat dari daftar doa syafaat di ibadah minggu maupun kelompok doa mereka tahu bahwa pembinanya mendoakan mereka. Mereka ingin supaya pembinanya mempunyai waktu yang lebih untuk mendoakan mereka secara khusus, seperti yang diungkapkan Pinky Gastuti. ${ }^{39}$ Jadi remaja membutuhkan pembina yang benar-benar mendoakan mereka dalam keseharian mereka, diminta atau tidak diminta.

Berdasarkan atas seluruh uraian di atas mengenai kebutuhan remaja bagi pembinanya, maka seorang pembina harus mengenal dan memahami apa yang menjadi kebutuhan dari remaja binaannya. Menjadi pembina yang betul-betul memiliki hati untuk pelayanan remaja dan bukan hanya sebagai pelayanan untuk mengisi waktu luang atau kekosongan formasi pelayanan saja.

Berdasarkan hasil analisis data, maka yang menjadi kesimpulan penelitian yang harus dilakukan dalam pembinaan pelayanan remaja terutama dalam perkembangan perilaku remaja adalah:

Pertama, masih ada remaja yang percaya pada pembinanya sebagai sahabat atau kakak rohani mereka dan mau mencurahkan masalah mereka, walau hanya sekitar kehidupan umum remaja mereka saja dan tidak pada masalah yang khusus.

Kedua, sebagian dari remaja belum mendapatkan waktu yang berkualitas dari para pembina remaja untuk dikonseling, kalau pun ada tidak sampai tuntas.

Ketiga, remaja merasa bahwa pembina memiliki kejelian yang baik dalam menangani remaja sesuai perkembangan perilaku mereka. Di mana remaja yang berperilaku positif dilibatkan dalam pelayanan yang lebih dalam. Sedangkan bagi remaja yang berperilaku negatif langsung dibimbing walaupun masih belum mendapatkan penanganan khusus.

Keempat, dibutuhkan kreativitas yang lebih dalam melaksanakan tata ibadah remaja sehingga memiliki daya tarik tersendiri bagi remaja tanpa

${ }^{39}$ Pinky Gastuti, Wawancara oleh Pembina, Tanjung Selor, 18 Mei 2014. 
mengurangi nilai yang harus dipahami remaja dalam tumbuh kembang kerohaniaan mereka.

Kelima, melalui doa para pembina dapat menghasilkan anak remaja yang memiliki perilaku yang berubah dan menjadi lebih baik sehingga mendorong remaja untuk setia beribadah.

\section{Kesimpulan}

Pembina remaja harus mengajarkan arti dan manfaat dari konseling, agar remaja dapat mengerti. Dan bila ada remaja yang membutuhkan bantuan dalam masa remaja mereka, terutama tumbuh kembangnya dalam perilakunya remaja tahu bahwa pembinanya mampu membantu memberi masukan atau saran sesuai firman Tuhan. Juga pembina perlu untuk memberi waktu yang cukup bagi remaja bila dibutuhkan.

\section{Sebagai Pemimpin Yang Memiliki Visi}

Pembina remaja perlu dan sangat penting untuk menyampaikan setiap visi yang akan dijalaninya selama melayani remaja. Apa yang menjadi visi kedepannya bagi kelangsungan pelayanan tersebut. Diperlukan kerjasama yang baik antara ketua pembina remaja dan pembina remaja lainnya agar supaya visi yang akan dijalankan dapat mencapai sasarannya.

\section{Sebagai Pemimpin Rohani}

Pembina remaja harus mempersiapkan setiap materi firman Tuhan yang akan disampaikan agar setiap remaja mengerti makna apa yang dapat diperoleh untuk mereka lakukan dalam kehidupannya. Selain itu pembina remaja harus menjadi teladan yang baik dalam kehidupan kesehariannya, baik dalam perkataan, perbuatan, ucapan dan tingkah lakunya. Contoh yang perlu dilakukan pembina sebagai pemimpin rohani bagi remajanya adalah mempolakan budaya baca Alkitab dan doa di setiap hari bagi remaja.

\section{Sebagai Sahabat}

Pembina remaja perlu membuat dirinya masuk dalam kebersamaan dengan remaja binaannya. Dengan cara lebih sering bertatap muka di luar ibadah remaja, mengadakan pertemuan rutin di tiap bulan dengan remaja, rekreasi bersama. Atau hal yang sangat mudah dilakukan, tetapi memiliki dampak yang sangat besar yaitu jogging di sore hari misalnya, untuk menjadikan diri pembina sebagai sahabat. Hal ini yang kadang kurang dipikirkan sebagai cara yang sebenarnya sangat mudah untuk dilakukan. Dan masih ada banyak cara yang lain dapat dilakukan, 
asalkan pembina benar-benar ingin menjadi bagian sahabat yang baik bagi mereka.

\section{Sebagai Pendoa Syafaat}

Pembina remaja perlu pula untuk selalu mendoakan remajanya baik diminta atau tidak. Lebih aktif untuk menanyakan keadaan mereka, mengunjungi remaja di rumah mereka, lalu mendoakan mereka secara syafaat. Hal ini akan memberi dampak yang sangat besar bagi remaja di mana mereka akan belajar menjadi seorang remaja yang gemar berdoa.

Jadi dengan adanya pembina remaja yang tahu benar fungsinya atau peranannya sebagai pembina remaja maka dapat menghasilkan:

Pertama, remaja yang memiliki kualitas pengetahuan firman Tuhan yang baik dan benar. Sehingga remaja dapat menjalani kehidupan masa remajanya tanpa adanya perubahan perilaku yang menuju pada arah yang negatif.

Kedua, dapat dijadikan sebagai acuan yang baik bagi pembina remaja selanjutnya dan dapat mendorong orang tua melakukan hal yang sama pada remaja saat berada dirumah.

Ketiga, dapat menumbuhkan rasa percaya diri anak remaja saat mengalami perilaku yang berbeda dan mereka tahu pada siapa dapat mencurahkan masalah yang sedang dihadapinya.

\section{Kepustakaan}

Buku-buku

Benson, Warren S. dan Mark H. Senter II. Pedoman Untuk Pelayanan Kaum Muda. Bandung: Kalam Hidup, 1993.

B. Hurlock, E. Psikologi Perkembangan Suatu Pendekatan Sepanjang Rentang Kehidupan. Jakarta: Erlangga, 1991.

Chapman, Gary. The Five Love Languages of Teenagers. Batam: Interaksara, 2003.

Dodson, Fitzhugh. Mendisiplinkan Anak dengan Kasih Sayang. Jakarta: BPK Gunung Mulia, 1988.

Drescher, John M. Tujuh Kebutuhan Anak. Jakarta: BPK Gunung Mulia, 2009.

Dyck, Anni. Tantangan Dan Kebutuhan Remaja, Seri Pendidikan Kristen 3. Malang: Dept. PAP/YPPII, 2001.

Grinnel, Ann. Pedoman Kepemimpinan Kaum Muda Dream Big Start Small. Jakarta: Departemen Pemuda GKII dan Departemen Pemuda C\&MA, 2011.

Hendricks, Howard G. Mengajar Untuk Mengubah hidup. Jakarta: Gloria Graffa, 2009. 
Keeley, Robert J. Menjadikan Anak-anak Kita Bertumbuh Dalam Iman. Yogyakarta: Penerbit ANDI, 2013.

Linda dan Richard Eyre, Mengajarkan Nilai-Nilai kepada Anak. Jakarta: Gramedia Pustaka Utama, 1999.

Morgan, Les. Mencabut 7 Ilalang Perusak Masa Remaja. Bandung: Kalam Hidup, 2004.

Natsir, Moh. Metode Penelitian. Jakarta: Ghalia Indonesia, 1988.

Nee, Watchman. 12 Bakul. Surabaya: Yayasan Perpustakaan Injil, 1993.

Palar, Ivone Bonyadone. Materi Kuliah PK Remaja-Pemuda. STT Jaffray: Makassar, 2010.

Palar, Ivone Bonyadone. Materi Kuliah: Teori dan Proses Perkembangan Anak. Makassar, 2014.

Rice, David. Mengendalikan Tingkah Laku Anak. Bandung: Kalam Hidup, 1987.

Ronda, Daniel. Leadership Wisdom. Bandung: Kalam Hidup, 2011.

Rumahlatu, Jerry. Psikologi Kepemimpinan. Penerbit: Cipta Varia Sarana, 2011.

Sahardjo, Hadi P. Konseling Krisis dan Terapi Singkat. Bandung: Pionir Jaya, 2008.

Sanders, Bill. Dari Remaja untuk Orang Tua. Bandung: Kalam Hidup, 1995.

Stanley, Andy. Visioneering. Yogyakarta: Penerbit ANDI, 1999.

\section{Wawancara}

Kuleh, Eli. Wawancara oleh Penulis, Tanjung Selor, 18 Mei 2014.

Yesaya, Sinang. Wawancara oleh Penulis, Tanjung Selor, 17 Mei 2014.

Sanus, Harju. Wawancara oleh Penulis, Tanjung Selor, 18 Mei 2014.

Unya, Elam. Wawancara oleh Penulis, Tanjung Selor, 16 Mei 2014.

Rio. Wawancara oleh Penulis, Tanjung Selor, 16 Mei 2014.

Laway, Dominggus. Wawancara oleh Penulis, Tanjung Selor, 19 Mei 2014.

Henock, Korie. Wawancara oleh Penulis, Tanjung Selor, 14 Mei 2014.

Nando, Wawancara oleh Penulis, Tanjung Selor, 19 Mei 2014.

Loveris, Wawancara oleh Penulis, Tanjung Selor, 13 Mei 2014.

Titin, Wawancara oleh Penulis, Tanjung Selor, 15 Mei 2014.

Lusia Kaleb, Wawancara oleh Penulis, Tanjung Selor, 18 Mei 2014.

Buding, Irang. Wawancara oleh Pembina, Tanjung Selor, 19 Mei 2014.

Tago'a, Ismail. Wawancara oleh Pembina, Tanjung Selor, 19 Mei 2014.

Lokbere, Resina. Wawancara oleh Penulis, Tanjung Selor, 12 Mei 2014.

Putri, Rima. Wawancara oleh Penulis, Tanjung Selor, 19 Mei 2014.

Mitha, Hana. Wawancara oleh Penulis, Tanjung Selor, 19 Mei 2014.

Gastuti, Pinky. Wawancara oleh Pembina, Tanjung Selor, 18 Mei 2014. 